\title{
Pemahaman Umat Islam tentang Kata Kalimah dalam Hubungan dengan Isa Almasih
}

\author{
Daniel Horatius Herman \\ SekolahTinggi Teologi Kalimantan \\ Korespondensi: danielhherman@sttkalimantan.ac.id
}

\begin{abstract}
Abstrak
Kesaksian Kristen di Indonesia, dalam perjumpaan dengan Islam, mengalami penolakan-penolakan. Berita tentang Yesus Kristus (atau Isa Almasih) diakui ada dalam kitab suci Islam, Al Qur'an, tetapi pada beberapa bagian berbeda dan bahkan bertolak belakang dengan Perjanjian Baru. Beberapa ajaran tentang Yesus dalam Al Qur'an dimaknai secara berbeda: Isa adalah Kalimatullah (firman Allah), Isa adalah rahmat, Isa akan datang kembali, Isa adalah hakim yang adil di akhir zaman dan lain-lain, semua berbeda dengan ajaran Perjanjian Baru. Orang Kristen, dalam kesaksian, mencoba menafsirkan dan menggunakan kesamaan terminologi-terminologi tersebut. Hal ini menimbulkan perdebatan dan tentu saja bertentangan dengan etika iman, di mana ajaran sebuah agama tidak dapat dijelaskan dari perspektif agama lain. Penelitian ini bertujuan memperoleh pandangan obyektif tentang Yesus Kristus dari pandangan Islam untuk pembentukan pemahaman awal untuk pemberitaan iman Kristen, tetapi penelitian tidak dimaksudkan untuk mencari pembenaran (verifikasi) terhadap iman Kristen. Penelitian ini hanya mencari penjelasan dari versi Islam tentang Yesus Kristus.
\end{abstract}

Kata-kata kunci: Isa Al Masih, Yesus Kristus, Inkarnasi, ciptaan, firman Allah, Kalimatullah

\begin{abstract}
Christian witness in Indonesia, in an encounter with Islam, experienced rejection. The message about Jesus Christ (or Isa Al Masih) is acknowledged exist in Islam's scripture, Al Qur'an, but has several different parts and even contrary to the New Testament. Some teachings about Jesus in the Qur'an are interpreted differently: 'Isa is the Kalimatullah (a word from God),' Isa is mercy, 'Isa will come again,' Isa is a justice Judge at the end of time and others, all that is different from the New Testament's teachings. Christians, in their testimonies, tried to interpret and used the same terms. This gives rise to debate and is of course contrary to the ethics of faith, where religion teachings cannot be explained by the perspective of other religions. This study aims to obtain an objective view of Jesus Christ from the Islamic view to form an initial understanding of the preaching of the Christian faith, but this study is not intended to seek justification (or verification) of the Christian faith. This study only seeks an explanation of the Islamic version of Jesus Christ.
\end{abstract}

Keywords: Isa Al Masih, Jesus Christ, Incarnation, creation, word of Allah, Kalimatullah 


\section{Pendahuluan}

\section{Latar Belakang Masalah}

Iman Kristen telah diberitakan sejak Yesus mengucapkan Amanat Agung-Nya, “...Kamu akan menjadi saksi-Ku di Yerusalem, di seluruh Yudea dan Samaria dan sampai ke ujung bumi." Di beberapa tempat di Indonesia, kesaksian Kristen menghadapi penolakan-penolakan, terutama dari umat Islam. D. W. Ellis menyebutkan lima alasan umat Islam menolak kekristenan: Alkitab, Kristus sebagai Anak Allah, Keilahian Yesus Kristus, Salib dan Trinitas. ${ }^{2} \mathrm{Hal}$ yang paling sering diperdebatkan adalah masalah-masalah sekitar Yesus Kristus (Isa Al Masih) terutama tentang keilahiannya. Keilahian Yesus menarik untuk dibahas karena menyangkut doktrin utama kekristenan. Bagian terpenting dalam adalah inkarnasi-Nya. Yohanes menyatakan bahwa Yesus adalah Firman yang menjadi manusia (Yoh 1:1,14).

Sementara itu beberapa bagian Al Qur'an memberi penghormatan kepada Yesus, seperti nabi $^{3}$, Rasul ${ }^{4}$, bahkan Yesus (Isa) disebutkan sebanyak 93 kali. $^{5}$ Qs. 3 Ali Imran 45 mengatakan bahwa Isa terkemuka di dunia dan akhirat. Sementara bagian lain tidak menyatakan keagungan yang sesuai dengan penghormatan tersebut. $^{6}$

Orang Kristen sering mereferensikan ayatayat Al Qur'an yang dianggap sejajar dengan ayat-ayat Alkitab untuk menunjukkan bahwa

${ }^{1}$ Kisah Para Rasul 1:8

${ }^{2}$ D. W. Ellis, Metode Penginjilan, (Jakarta: Yayasan Komunikasi Bina Kasih/OMF, 1989),190-1

${ }^{3}$ S. H. Nasr, Islam dalam cita dan Fakta, pen. Abdurrahman Wahid dan Hashim Wahid, (Jakarta: Lembaga Penunjang Pembangunan Nasional, 1983), 17

${ }^{4}$ Muhammad Abdullah Syarqawy, Yesus dalam Pandangan Al-Ghazali: Analisa Pemikir Besar Islam tentang Dogma Trinitas, pen. Hasan Abrori, Diedit oleh Masyhud SM dan Ibnu Hasan, (t. tp.: Pustaka Da'i, 1994), 225

${ }^{5} \mathrm{Al}$ Fadi, Abdullah, "Almasih dalam Injil dan Al Qur'an," dalam Buletin Midrash Talmiddim No. 3 Tahun I, 1999, (Bekasi: Yayasan Kaki Dian Emas, 1999), 8

${ }^{6} \mathrm{~J}$. Bakker, Piagam Konsili vatikan II, (Yogyakarta: Kanisius, 1972), 66-7.
Yesus Kristus adalah inkarnasi Allah atau Yesus Kristus adalah Allah.

Pembuktian dari Al Qur'an dapat dikelompokkan sebagai berikut, ${ }^{7}$ Isa Almasih adalah inkarnasi Firman Allah; ${ }^{8}$ Isa Almasih adalah Roh Allah atau penjelmaan dari Roh Allah; ${ }^{9}$ Isa Almasih memegang peran yang hanya menjadi hak Allah: Menciptakan makhluk hidup ${ }^{10}$ dan Isa Almasih adalah Hakim yang adil pada akhir zaman ${ }^{11}$

Rujukan-rujukan di atas menarik untuk dibahas, terutama pandangan Isa Almasih adalah kalimatullah. Pandangan ini dianggap sama atau setidaknya sejajar dengan Yohanes 1:1 dan 14 juga 1 Yohanes 1:1-3, yaitu Yesus Kristus adalah inkarnasi Firman Allah.

Sebaliknya umat Islam mengatakan tidak ada inkarnasi Ilahi. Perspektif Islam didasarkan pada pandangan tentang Tuhan sebagaimana Ia ada, bukan Tuhan yang berinkarnasi dalam sejarah. ${ }^{12}$ Isa tidak pernah dipandang sebagai inkarnasi, melainkan sebagai nabi. ${ }^{13}$

Hal ini menunjukkan adanya perbedaan penafsiran di antara umat Islam dan Kristen tentang firman dan Yesus Kristus. Ayat-ayat Al Qur'an yang dijadikan referensi oleh orang Kristen tidak ditafsirkan dengan cara yang sama oleh umat Islam.

Suprayogo dan Tobroni mengatakan bahwa kebenaran suatu agama tidak dapat dinilai oleh

${ }^{7}$ Dikumpulkan dari Suradi Ben Abraham, Penginjilan Pribadi, (t. tp.: oleh Penulis, t.th), 104-16; Rahasia Jalan ke Surga, (Jakarta: Dakwah Ukhuwah, traktat, t.th), Edhi Sapto Wedha, Islamologi, (t.tp: oleh Penulis, fotokopi, t. th), 2-3 dan P. Agusman, Sedapat Mungkin: Aspek-aspek Komunikasi Lintas Budaya, (t. tp. : oleh penulis, 1996), 133.

${ }^{8}$ Qs 3 Ali Imraan 45; Qs 4 An Nisaa 171; Hadits Sahih Bukhari No. 1496; Hadits Shahih Muslin 46, bandingkan dengan Yohanes 1:1,14 dan I Yoh 1:1-3

9 Qs 19 Maryam 17; Qs 21 Al Anbiyaa 91; Hadits Anas bin Malik hal 72, bandingkan Matius 1:18, Lukas $1: 35$

${ }^{10}$ Qs. 3 Ali Imraan 48, bandingkan dengan Yohanes 1:1-3

${ }^{11}$ Qs. 4 An Nisaa 159; Hadits Sahih Bukhary 1090, Hadits Sahih Muslim 127, bandingkan dengan Kis 10:42; II Tim 4:8. H. Amos, Upacara Ibadah Haji, (Jakarta: oleh penulis, 1997), 14.

${ }^{12}$ S. H. Nasr, Islam dalam cita dan Fakta, 3

${ }^{13}$ Ibid., 17. 
agama lain. ${ }^{14}$ Berdasarkan hal tersebut maka masalah ini menjadi menarik untuk diteliti. Sebuah pertanyaan dapat dikemukakan untuk menjadi masalah atau fokus dalam penelitian ini, yaitu "Apakah Pemahaman umat Islam tentang Kata kalimah dalam hubungan dengan Isa Almasih?"

\section{Rumusan Masalah}

Penelitian ini akan didasarkan pada pertanyaan-pertanyaan, pertama, apakah makna kata kalimah dalam ajaran Islam? Kedua, apakah pemahaman umat Islam tentang kata kalimah dalam hubungan dengan Isa Almasih seperti tertulis dalam Al Qur'an? Ketiga, apakah pemahaman umat Islam tentang kata kalimah dalam hubungan dengan Isa Almasih seperti tertulis dalam Hadits?

\section{Batasan Masalah}

Penelitian ini dibatasi pada pemahaman umat Islam tentang kata kalimah dalam hubungan dengan Isa Almasih. Data Penelitian diperoleh dengan wawancara mendalam dan literatur. Penelitian ini tidak membahas tentang topik-topik lain dalam perdebatan Kristen-Islam. Penelitian ini juga tidak dimaksudkan untuk menentukan mana yang benar dan yang salah (verifikasi) tetapi untuk mencari penjelasan dari versi Islam tentang Isa Almasih. Jadi penelitian ini bersifat eksploratif dan deskriptif.

\section{Tujuan Penelitian}

Penelitian ini dibuat untuk memperoleh pandangan obyektif terhadap ajaran Islam dan diharapkan agar masalah yang dikemukakan dapat menambah pengertian baru tentang pemahaman umat Islam terhadap tema dalam Al Qur'an dan Hadits, khususnya tentang Isa Almasih.

\footnotetext{
${ }^{14}$ Imam Suprayogo dan Tobroni, Metodologi
} Penelitian Sosial-Agama, (Bandung: Remaja Rosdakarya, 2001), 21

\section{Manfaat Penelitian}

Penelitian ini, dapat menjadi pemahaman awal terhadap kepercayaan Islam yang berhubungan dengan Kristologi dan dapat menjadi bahan kajian untuk penelitian lebih lanjut dalam hubungan dengan pemahaman umat Islam tentang Yesus Kristus. Penelitian ini juga dapat menjadi prasuposisi untuk dialog dengan umat Islam mengenai tema Kristologi agar tidak terjadi kesimpangsiuran terminologi dan dapat menambah wawasan sehubungan dengan Kristologi ditinjau dari sudut pandang Islam.

\section{Tinjauan Pustaka}

Pemahaman umat Islam tentang Isa Almasih selalu merujuk pada Al Qur'an dan Hadits, karena itu pemahaman tentang $\mathrm{Al}$ Qur'an dan Hadits diperlukan bagi pembahasan penelitian ini.

Bagian ini akan membahas secara singkat, dan padat tentang Al Qur'an dan pandangan umat Islam terhadapnya, latar belakang singkat Surat Ali Imran dan Surat An Nisa, juga Hadits dan pandangan umat Islam terhadapnya.

\section{Al Qur'an}

Al Qur'an, diturunkan secara bertahap ${ }^{15}$ kepada Nabi Muhammad ${ }^{16}$ selama kira-kira dua puluh tiga tahun ${ }^{17}$ lebih kurang 13 tahun di Makkah ${ }^{18}$ dan 10 tahun di Madinah. ${ }^{19}$ Ayat-ayat ini dihafalkan oleh para Sahabat dan sebagian ditulis pada potongan kayu, pelepah Kurma dan sejenisnya. ${ }^{20}$ Sekretaris yang setia mencatat ayat-

${ }^{15}$ Diterjemahkan dari Sahih al-Bukhari, Vol. 6, p. 474 dalam Gilchrist, The Qur'an: The Scripture of Islam.

${ }^{16}$ Nasution, Islam ditinjau dari berbagai Aspeknya, 25.

${ }^{17}$ Harun Nasution, Islam ditinjau dari berbagai Aspeknya, Vol. I, II (Jakarta: UI Press,1974), 27-8.

${ }^{18}$ Riva'i Burhanuddin, Sejarah Alkitab dan $\mathrm{Al}$ Qur'an, (Jakarta: C.V. Baru, 1981), 86.

${ }^{19}$ Ibid., 86.

${ }^{20}$ John Gilchrist, The Qur'an: The Scripture of Islam, dalam The World of Islam: Resources for Understanding, [CD-ROM], (Pasadena, California: Global Mapping International, 2000). 
ayat Qur'an adalah Zaid Ibn Thabit. ${ }^{21} 92$ surat diturunkan di Makkah, surat-surat ini pendekpendek dan disebut Makkiyyah. ${ }^{22} 22$ surat diturunkan di Madinah, surat-surat ini panjangpanjang dan disebut Madaniyyah. ${ }^{23}$

Sejak kelahiran, hingga saat akan wafat, seorang Muslim hidup dengan Al Qur'an. ${ }^{24} \mathrm{Al}$ Qur'an yang dipercayai sebagai kata-kata Tuhan ${ }^{25}$ dan terdiri atas doktrin, ringkasan sejarah dan sesuatu yang sulit dijelaskan dalam bahasa modern yang disebut "magi" yang agung; Maksudnya Al Qur'an mempunyai kekuatan, ayat-ayatnya menyerupai azimat yang melindungi manusia. $^{26}$

\section{Surat 3 Ali Imran}

Nama Surat yang menjelaskan tentang keluarga Imran ini, diambil dari ayat 33, Ali Imran. ${ }^{27}$ Surat ini diturunkan sesudah Qs. $8 \mathrm{Al}$ Anfaal, ${ }^{28}$ terdiri dari 200 ayat. $^{29}$ Surat ini dialamatkan secara khusus kepada Umat Berkitab (Ahlul Kitab) ${ }^{30}$ Yahudi dan Nasrani, juga kepada para pengikut Nabi Muhammad. Surat ini memperingatkan Orang Yahudi dan Nasrani akan kesalahan kepercayaan dan kejahatan moral, dan dinasehatkan untuk menerima, kebenaran Al Qur'an. Dan ajaran Nabi Muhammad yang mengajar jalan hidup yang sama yang dikhotbahkan oleh para nabi

\footnotetext{
${ }^{21}$ Sahih al-Bukhari, Vol. 5, p. 97, dalam Gilchrist, The Qur'an: The Scripture of Islam.

${ }^{22}$ Maulana Muhammad Ali, The Religion of Islam. (New Delhi: S. Chan and co. Ltd., t.th.), 48-9 dikutip oleh Yoseph Soedarso, Riwayat Hidup Muhammad dan Pokokpokok Ajaran Islam, Diktat Kuliah Islamologi, Semarang: STBI, t.th., 35

${ }^{23}$ Ibid.

${ }^{24}$ Nasr, Islam dalam cita dan Fakta, 21.

${ }^{25}$ Ibid., 22.

${ }^{26}$ Ibid., 28.

${ }^{27}$ Lihat Bustami A. Gani, dkk., Al Qur'an dan Tafsirnya, 10 jilid, (Jakarta: Departemen Agama RI, 1993), I:510.

${ }^{28}$ Jalaluddin $\mathrm{Al}$ Mahalaliy dan Jalaluddin As Suyuthi, Tafsir Jalalain berikut Asbaabun Nuzul, 4 jilid. Diterjemahkan oleh Mahyudin Syaf dan Bahrun Abubakar. (Bandung: Sinar Baru, 1990), I:302.

${ }^{29}$ Ibid.

${ }^{30} \mathrm{Al}$ Mawdudi, Surah Information: 3 Ali-Imran dalam Gilchrist, The Meaning of The Holy Qur'an.
}

dan jalan Allah; Kemudian komunitas Islam dideklarasikan sebagai komunitas terbaik, yang ditunjuk sebagai pembawa kebenaran dan tanggung jawab memperbarui dunia. juga peringatan bagi Muslimin belajar dari kemerosotan agama dan moral masyarakat masa itu. $^{31}$

\section{Surat 4 An Nisa}

Surat ini searah dengan tiga masalah yang dihadapi Nabi Muhammad, pada waktu diturunkan. Pertama, Beliau memperkenal-kan moral yang baru, budaya, sosial, ekonomi dan politik. Kedua, perjuangan pahit melawan kaum Musyrik Arab, suku-suku Yahudi dan Orangorang munafik yang menentang misi perubahannya. Ketiga, status kaum wanita dalam masyarakat, hukum anak yatim, peraturan harta warisan, dan perintah-perintah diberikan untuk menyelasaikan masalah ekonomi. ${ }^{32}$ Surat An Nisa (wanita) adalah surat Madaniyyah terdiri atas 176 ayat. $^{33}$

\section{Hadits}

Hadits adalah kumpulan perkataan dan perbuatan Nabi Muhammad. ${ }^{34}$ Bagi umat Islam, Hadits merupakan sumber perundang-undangan Islam. ${ }^{35}$ Umat Islam diperintahkan untuk mengikuti As Sunnah (Al Hadits) seperti mengikuti Al Qur'an ${ }^{36}$ karena keduanya sama pentingnya.

Hadits yang diakui shahih mempunyai kedudukan yang sama dengan Al Qur'an dan wajib diikuti. ${ }^{37}$ Hadits diperlukan untuk menjelaskan hukum dalam Al Qur'an..$^{38}$ Tetapi, meskipun Hadits merupakan sumber hukum Islam, umat Islam menetapkan bahwa Al Qur'an

\footnotetext{
${ }^{31}$ ibid.

${ }^{32} \mathrm{Al}$ Mawdudi, Surah Information, dalam Gilchrist,
} The Qur'an: The Scripture of Islam.

${ }^{33}$ Gani, dkk., Al Qur'an dan Tafsirnya, II:115

${ }^{34}$ Kenneth W. Morgan, Islam Jalan Mutlak. (Jakarta:PT Pembangunan, 1962), 35, dalam Soedarso, 36.

${ }^{35}$ Ash Shiddiqie, Sejarah dan Pengantar Ilmu Hadits, 148.

${ }^{36}$ Ibid., 145

${ }^{37}$ Ibid., 147

${ }^{38}$ Ibid., 154-5 mengutip Ahmad Ibn Hanbal: 221 
itu dasar yang pertama dan Al Hadits (As Sunnah) dasar kedua ${ }^{39}$

Tidak setiap Hadits memiliki kekuatan sebagai sumber hukum. Umat Islam membagi Hadits menjadi tiga derajat, yaitu Hadits Shahih, Hadits Hasan dan Hadits Dla'if. Hadits yang menurut pemeriksaan benar berasal dari Nabi Muhammad, dinamakan "Shahih". ${ }^{40}$ Hadits Hasan adalah Hadits yang benar berasal dari Nabi Muhammad tetapi memiliki beberapa kelemahan. Sedangkan Hadits yang menurut pemeriksaan, tidak benar atau belum nyata benar dari Nabi Muhammad disebut "Dla'if" atau "lemah." 41

\section{Shahih Bukhary}

Al Bukhary, ${ }^{42}$ (Abu Abdulah Muhammad ibn Isma'il ibn Ibrahim ibn Al Mughirah Al Ja'fy) lahir pada tahun 194 H (kira-kira 810 AD). Ayahnya, seorang Ahli Hadits, meninggal waktu Bukhary masih kecil, karena itu Bukhary dididik ibunya. Pada usia sepuluh tahun Bukhary mulai menghafal hadits dan pada masa kanak-kanak telah menghafal 70.000 hadits lengkap dengan sanadnya. Pada usia 16 tahun ia mencari ulamaulama hadits di berbagai kota. Bukhary wafat tahun $256 \mathrm{H}$ (870 AD).

Bukhary adalah orang pertama yang menyusun Hadits, Bukhary menamainya Al Jami'ush shahih Al Musnadu min Hadits Rasul $\mathrm{SAW}^{43}$ dan membaginya ke dalam 97 kitab, 3451 bab. $^{44}$

Mayoritas ulama hadits sepakat menetapkan shahih Al Bukhary itu sebagai kitab shahih sesudah Al Qur'an ${ }^{45}$ bahkan para ulama menerimanya tanpa memeriksa kembali. ${ }^{46}$ Alkaf

\footnotetext{
${ }^{39}$ Ibid., 148

${ }^{40}$ A. Qadir Hasan, Ilmu Mushthalah Hadits, (Bandung: C.V. Diponegoro, 1994), 18

${ }^{41}$ A. Qadir Hasan, Ilmu Mushthalah Hadits, (Bandung: C.V. Diponegoro, 1994), 18

${ }^{42}$ Ash Shiddiqie, Sejarah dan Pengantar Ilmu Hadits $292-5$.

${ }^{43}$ ibid

${ }^{44}$ Ibid., 85

${ }^{45}$ Ibid., 84 lihat juga kata pengantar Hussein Bahreisj, Al Jami'ush Shahih, (Hadits Shahih): Bukhary Muslim, (Surabaya: CV Karya Utama, t.th.), iv

${ }^{46}$ ibid.
}

mengatakan Kitab Shahih Bukhary menempati posisi kedua sesudah Al Qur'an dalam pengambilan hukum-hukum Islam. ${ }^{47}$

\section{Shahih Muslim}

Muslim lahir pada tahun 206 H (822 AD), wafat di Naisabury tahun $261 \mathrm{H}$ (877 AD). Nama lengkapnya adalah Abdul Husain Muslim ibn Al Hajjaj ibn Muslim Al Qusyairy An Naisabury. ${ }^{48}$ Saat Al Bukhary tinggal di Naisabury, Muslim sering mengunjunginya. Muslim terus berguru kepadanya dan pada akhirnya membuat sebuah kitab shahih yang dikumpulkan dan disarikan dari sekitar 300.000 hadits. ${ }^{49}$ Kitab Shahihnya memuat 7275 Hadits.

Shahih Muslim lebih baik susunannya daripada Shahih Al Bukhary ${ }^{50}$ dan diakui sebagai hadits kedua yang menjadi pegangan ${ }^{51}$ yang dianggap menyamai Al Bukhary.

\section{Isa Al Masih dalam Ajaran Islam}

Beberapa ajaran Islam mengenai Isa serupa dengan Perjanjian Baru, tetapi terdapat juga perbedaan yang terkadang bertolak belakang. Isa diakui sebagai nabi dan rasul, tetapi bukan sebagai Tuhan $(\mathrm{God}){ }^{52}$

Umat Islam memercayai kelahiran Isa dari perawan Maryam (Maria). ${ }^{53}$ Namun Yusuf yang kemudian menikah Maria tidak dikenal dalam Islam, karena itu Isa lebih dikenal sebagai Ibnu Maryam. ${ }^{54}$ Menurut Al Qur'an, Isa lahir di bawah pohon kurma. ${ }^{55}$ Isapun dapat berbicara sewaktu bayi untuk membela ibunya dari tuduhan berzina. ${ }^{56}$

${ }^{47}$ Idrus H. Alkaf, Penerjemah, Ikhtisar Hadits Shahih Bukhary, (Surabaya: C. V. Karya Utama, t. th), iii

${ }^{48}$ lihat Ash Shiddiqie, 296-7

${ }^{49}$ ibid.

${ }^{50}$ Ibid., 86.

${ }^{51}$ ibid.

${ }^{52}$ Arifin Assagaf, wawancara dengan Peneliti.

${ }^{53}$ Qs. 3 Ali Imran 45-47

${ }^{54}$ Saudah mendaftarkan sebanyak 22 kali, Konkordansi Qur'an: Panduan Kata dalam Mencari Ayat Qur'an.

${ }^{55}$ Qs. 19 Maryam 16-26

${ }^{56}$ Qs. 19 Maryam 27-34. 
Mujizat-mujizat Isa disebutkan dalam $\mathrm{Al}$ Qur'an, bahkan Isa menciptakan seekor burung, ${ }^{57}$ menyembuhkan orang yang buta sejak lahir, menyembuhkan penyakit kusta dan membangkitkan orang mati, semua atas izin Allah. $^{58}$

Karena mujizat-mujizat-Nya, Isa dituduh melakukan sihir. $^{59}$ Isa juga menghadapi perlawanan dari orang-orang Yahudi $^{60}$ yang ingin membunuh-Nya. ${ }^{61}$ Orang-orang Yahudi menganggap telah berhasil membunuh Isa. $^{62}$ Mengenai kematian Isa, Al Qur'an menyang-kal penyaliban-Nya ${ }^{63}$ dan menyatakan bahwa Isa diangkat kepada Allah. ${ }^{64}$ Qs. 19 Maryam 33 memuat doa Isa untuk memohon kesejahteraan pada waktu Ia dilahir, waktu diwafatkan, maupun waktu dibangkitkan, tetapi ayat ini tidak dipahami sebagai pernyataan bahwa Isa telah wafat dan kemudian bangkit.

Umat Islam percaya Isa akan datang kembali dan menjadi hakim pada hari kiamat. ${ }^{65}$ Sebagian umat Islam mengatakan bahwa Isa adalah Imam Mahdi $^{66}$ Sebagian lagi berkata bahwa Imam Mahdi adalah orang lain. ${ }^{67}$ Mohammad Abdai Rathomy berkata, Isa adalah Mahdi yang termulia dari Mahdi-mahdi lain. ${ }^{68}$ Kedatangan Isa kembali pada akhir zaman tidak dipandang begitu penting dalam Islam, ${ }^{69}$ karena pada akhirnya Isa akan diadili Allah. ${ }^{70}$

\footnotetext{
${ }^{57}$ Qs. 3 Ali Imran 49.
}

${ }^{58}$ Qs. 5 Al Maidah 110.

${ }^{59}$ Qs. 5 Al Maidah 110.

${ }^{60}$ Qs. 19 Maryam 43.

${ }^{61}$ Qs. 5 Al Maidah 110.

${ }^{62}$ Qs. 4 An Nisa 157.

${ }^{63}$ Qs. 4 An Nisa 157-8.

${ }^{64}$ Qs. 19 Maryam 158.

${ }^{65}$ Qs. 4 An Nisaa 159, Hadits Sahih Bukhary 1090, Hadits Sahih Muslim 127.

${ }^{66}$ Didasarkan pada Hadits Ibnu Majah, dikutip oleh H. M. Arsyad Thallib Lubis, Imam Mahdi, (Medan: Firma Islamiyah, 1967), 44.

${ }^{67}$ Didasarkan pada beberapa hadits.

${ }^{68}$ Mohammad Abdai Rathomy, Inilah Hari Pembalasan. (Bandung: PT Al Maiarif, t.th), 37.

${ }^{69}$ Wienata Sairin, Tempat dan Peran Yesus di Hari Kiamat: Menurut Ajaran Islam, (Jakarta: Pustaka Sinar Harapan, 1997), 65.

${ }^{70}$ Qs. 7 Al A'raaf 6

\section{Metodologi Penelitian}

Penelitian ini akan menggunakan Metode Penelitian Kualitatif dan bersifat deskriptif. Penelitian pustaka juga dilakukan sebagai pendukung penelitian ini.

\section{Teknik Pengumpulan Data}

Penelitian kualitatif biasa menggunakan Wawancara Mendalam dan Pengamatan, tetapi penelitian ini hanya menggunakan Wawancara Mendalam tanpa melibatkan Pengamatan. Sevilla dkk. menjelaskan bahwa Penelitian Kualitatif dapat dilakukan tanpa Pengamatan. ${ }^{71}$ Irianto dan Bungin bahkan menjelaskan bahwa Wawancara Mendalam adalah alat utama dalam Penelitian Kualitatif. $^{72}$ Wawancara Mendalam bersifat fleksibel, dapat berubah sesuai kondisi subyek $^{73}$ dan memungkinkan perubahan, pengulangan, serta penguraian pertanyaan.

Mengenai Informan, Penelitian Kualitatif tidak menggunakan sampel acak tetapi sampel bertujuan (Purposive Sample), ${ }^{74}$ sampel ini lebih selektif. $^{75}$ Karena data dalam Penelitian Kualitatif digunakan tidak dalam rangka mewakili populasi tapi mewakili informasi. ${ }^{76}$ Karena itu tidak ada kriteria baku mengenai jumlah Informan yang harus diwawancarai. Peneliti berhenti melakukan wawancara jika data sudah jenuh. Artinya tidak lagi ditemukan aspek baru dari fokus yang diteliti. ${ }^{77}$

Penelitian ini juga menggunakan teknik Snowball Sampling, yaitu teknik pengumpulan

${ }^{71}$ Lihat Consuelo G. Sevilla, dkk., Pengantar Metode Penelitian, terj. Alimuddun Tuwu, (Jakarta: Penerbit Universitas Indonesia (UI-Press), 1993), 158

${ }^{72}$ Heru Irianto dan Burhan Bungin, Pokok-pokok Penting tentang Wawancara dalam Burhan Bungin, Ed., Metode Penelitian Kualitatif, (Jakarta: PT RajaGrafindo Persada, 2001), 110.

${ }^{73}$ Deddy Mulyana, Metodologi Penelitian Kualitatif: Paradigma Baru Ilmu Komunikasi dan Ilmu Sosial Lainnya, (Bandung: PT Remaja RosdaKarya, 2001), 181.

${ }^{74}$ Lexy Moleong, Metodelogi Penelitian Kualitatif, (Bandung: PT Remaja Rosdakarya, 2002), 165.

${ }^{75}$ Suprajogo dan Tobroni, Metodologi Penelitian Sosial-Agama, 165, lihat juga Moleong, Metodelogi Penelitian Kualitatif, 137.

${ }^{76}$ Ibid., 165.

${ }^{77}$ Mulyana, ibid.,182. 
data yang digunakan jika peneliti tidak mengetahui siapa yang harus diwawancarai, ${ }^{78}$ Peneliti, dengan snowball sampling ini, mendapatkan petunjuk dari satu informan mengenai informan yang lainnya.

\section{Pembahasan}

\section{Makna Kata kalimah}

Secara Etimologi, kata kalimah (كلمَِه ) bisa berarti mujizat, keterangan, ilham, tanda-tanda, hukum-hukum, aturan-aturan, dan lain-lain. ${ }^{79}$ Secara terminologi, kata kalimah berasal dari kata kalam, ${ }^{80}$ yang berarti perkataan ${ }^{81}$ atau kata-kata. ${ }^{82}$ Kalam Allah berarti kata-kata Allah. ${ }^{83}$ Tetapi kata kalimah tidak selalu diartikan firman. Kata kalimah bisa berarti ujian, atau ketetapan. ${ }^{84}$

\section{Deskripsi Fokus Penelitian}

\section{Qs. 3 Ali Imran 45}

Atas pertanyaan "Apakah pemahaman Anda tentang kata dengan kalimat daripada-Nya (bikalimatin minhu) dalam Qs. 3 Ali Imran 45?" 85

Tiga informan menjawab bahwa kata kalimah berarti tanda-tanda, tanda kekuasaan-

\footnotetext{
${ }^{78}$ Suprajogo dan Tobroni, ibid., 166. Moleong juga memberi penjelasan yang sama mengenai Snowball Sampling, lihat Moleong, ibid., 166.

${ }^{79}$ Hamang, Wawancara dengan Peneliti.

${ }^{80}$ Maidin, Wawancara dengan Peneliti, Kinontoa juga mengatakan hal yang sama.

${ }^{81}$ Kinontoa, wawancara dengan Peneliti.

${ }^{82}$ Mursyid, ibid. Lihat juga Munawwir, Kamus $\mathrm{Al}$ Munawwir: Arab Indonesia Terlengkap, pada catatan kaki 109 penelitian ini, dan H. Mahmud Yunus, Kamus ArabIndonesia, (Jakarta: PT Hidakarya Agung, 1972)., pada catatan kaki 110 penelitian ini.

${ }^{83}$ Maidin, Wawancara dengan Peneliti.

${ }^{84}$ Mastur, Wawancara dengan Peneliti.

${ }^{85}$ (Ingatlah) Ketika malaikat berkata: "Hai Maryam sesungguhnya Allah mengembirakan kamu (dengan kelahiran seorang putra yg diciptakan) dengan kalimat (yang datang) daripada-Nya, namanya Almasih Isa putra Maryam, seorang terkemuka di dunia dan di akhirat dan salah seorang di antara orang-orang yang didekatkan (kepada) Allah. Al Quran dan Terjemahnya, diterbitkan untuk Departemen Agama Republik Indonesia. (Semarang: CV Toha Putra, 1989), 83.
}

Nya atau bukti kekuasaan-Nya. ${ }^{86}$ Pertama, kalimah bisa berarti tanda-tanda, bisa berarti ilham. Kata kalimah dalam ayat ini berarti tandatanda akan kelahiran seorang anak (kehamilan) dari Tuhan. Isa adalah bukti kemahakuasaan Tuhan. Kelahiran Isa adalah seperti kelahiran tiga orang lainnya dalam Al Qur'an yaitu Ishak yang lahir waktu Ibrahim sudah sangat tua, istrinya mandul dan tidak mungkin lagi punya anak. Inipun adalah kekuasaan Allah. Kemudian nabi Yahya di mana nabi Zakharia juga sudah tua dan istrinya mandul. Yang ketiga... (informan lupa), dan yang terakhir adalah Isa. Semuanya lahir sebagai bukti kemahakuasaan Allah. ${ }^{87}$ Kedua, kalimah juga berarti tanda-tanda kekuasaan-Nya. ${ }^{88}$

Kemudian frasa bikalimatin minhu berarti membenarkan kedatangan seorang nabi (bukan Tuhan) yang diciptakan dengan kalimat kun (jadilah) tanpa seorang Bapak yaitu nabi Isa. Dalam hal ini, Maryam akan mengandung dan melahirkan nabi Isa tanpa suami. Ketika Maryam pulang dengan membawa bayinya; orang Yahudi menuduh bahwa Maryam telah berbuat zina. Untuk membersihkan tuduhan itu Allah berfirman (sebagai penyangkal) bahwa roh yang ada dalam rahim Maryam adalah roh (milik) Allah dalam arti kalam hawadits. Sifatnya baru bukan kekal. Isu waktu itu, Isa lahir dari seorang perempuan tanpa suami menjadi perhatian umat. Ketiga, Kalimat Allah berarti tanda kekuasaan Allah. Semua ciptaan Allah dapat disebut kalimat Allah (sunnatullah). ${ }^{89}$

Lima jawaban yang lain menjelaskan bahwa kata kalimah berhubungan dengan penciptaan. Pertama, kalimah adalah firman dari Allah yaitu kun (jadilah). ${ }^{90}$ Kedua, ketika malaikat berkata kepada Maryam, ia membawa kabar gembira dari Allah bahwa Maryam akan mendapat seorang

\footnotetext{
${ }^{86}$ Lihat Lampiran B-1, B-3, dan B-4.

${ }^{87}$ Lihat Lampiran B-1,

${ }^{88}$ Lihat Lampiran B-3.

${ }^{89}$ Lihat Lampiran B-4.

${ }^{90}$ Lihat juga penjelasan dari Qs. 3 Ali Imran 59 yang
} masih dalam konteks yang sama "Sesungguhnya misal (penciptaan) Isa disisi Allah adalah seperti (Penciptaan) Adam. Allah menciptakan Adam dari tanah, kemudian Allah berfirman kepadanya, jadilah (seorang manusia) maka jadilah dia." Lihat Lampiran B-5. 
putera yang terkemuka di dunia dan akhirat, Maryam bingung karena belum pernah disentuh laki-laki. Malakat Jibril berkata bahwa tidak ada yang mustahil bagi Allah, Allah cukup mengatakan kun fa yakun. Kemudian frasa dengan kalimat dari pada-Nya berarti penciptaan Isa Almasih hanya dengan kun fa yakun. ${ }^{91}$ Ketiga kata kalimah berasal dari kata kalam artinya perkataan. Frasa bikalimatin minhu berarti penciptaan dengan kata kun (jadilah). ${ }^{92}$ Keempat, frasa dengan kalimat daripada-Nya berarti Isa diciptakan dengan kalimat kun fa yakun. Perhatikan Qs 3 Ali Imran 47, cerita ini dimulai dari ayat 42 sampai 63. Kata kalimat (kun fa yakun) adalah proses. Jadi kelahiran Isa adalah melalui proses yang dimulai dengan kalimat (kun). ${ }^{93}$ Kelima kata kalimah berarti ciptaan Tuhan.

Seorang informan memberi jawaban yang lain yaitu bahwa kata kalimah berarti pemberitahuan, kata kalimah berasal dari kata kalam yang berarti ucapan. Kalamullah berarti ucapan Allah. Frasa kalimat dari pada-Nya berarti pemberitahuan (bisikan) kepada Maryam bahwa Maryam akan mempunyai putera yang kejadiannya seperti nabi Adam yang tidak punya bapak. $^{94}$

\section{Qs. 4 An Nisa 171.}

Terhadap pertanyaan kedua yaitu pemahaman terhadap ungkapan dan kalimatNya (wakalimatuhu) dalam Qs. 4 An Nisa 171 terdapat jawaban-jawaban berikut,

Empat informan menjawab bahwa kata kalimat-Nya ada hubungan dengan kuasa Allah, kekuasaan-Nya, kekuasaan Tuhan, tanda-tanda kekuasaan-Nya, Pertama, semua nabi termasuk Isa adalah utusan Allah yang menyampaikan

\footnotetext{
${ }^{91}$ Lihat Lampiran B-7.

${ }^{92}$ bandingkan dengan Qs. 3 Ali Imran 59 tentang penciptaan Adam. Allah berfirman kun fayakun maka jadilah Isa. Bedanya Isa dikandung oleh Maryam, Adam tidak dilahirkan karena manusia pertama. Lihat juga catatan kaki Al Quran nomor 193. kun adalah perintah fayakun adalah proses lihat konteks ceritanya (3:46-47) dengan kalimatnya maka Isa tercipta. Lihat Lampiran B-6.

${ }^{93}$ Lihat Lampiran B-8.

${ }^{94}$ lihat Lampiran B-2.
}

wahyu Allah. Isa Almasih sejak lahir sudah jadi nabi. Berbeda dengan Muhammad yang dipanggil menjadi nabi pada usia 40 tahun. Isa adalah kekhususan, tidak seperti manusia biasa. Maryam hamil karena kuasa Allah. Dapat dikatakan hal ini adalah sesuatu yang gaib karena penciptaannya dengan kalimat kun fa yakun. ${ }^{95}$ Kedua, arti kalimah dalam ayat ini adalah kekuasaan-Nya. Maksudnya Isa lahir atas kekuasaan Allah. $^{96}$ Ketiga, kalimah berarti kekuasaan Tuhan yang atas izin, kehendak dan kemauan-Nya untuk menjadikan Isa tanpa seorang bapak. Ayat ini menjelaskan kepada ahlul kitab agar tidak mengada-ada (membuat keputusan yang berlebihan), tentang Allah karena Isa hanyalah utusan Allah. Kalimat-Nya berarti Isa adalah utusan-Nya yang membawa firman. ${ }^{97}$ Keempat. kata kalimah berarti tandatanda kekuasaan-Nya. ${ }^{98}$

Empat informan menjawab bahwa kalimatNya berhubungan dengan ciptaan dan penciptaan. Pertama, Penafsiran yang paling dekat terhadap ungkapan ini adalah bahwa Allah menciptakan Isa Almasih dengan perintah kun (jadilah), sebagaimana disebut dalam beberapa ayat Al Quran yaitu kun fa yakun, (jadilah maka jadilah). Kalimat inilah yang disampaikan kepada Maryam. Maka terciptalah Isa di dalam rahimnya tanpa sperma seorang ayah, sebagaimana biasanya dalam kehidupan manusia selain Adam. Kalimat yang dapat menjadikan segala sesuatu ini ( $k u n)$ dari tidak ada menjadi ada, tidak mengherankan kalau Ia menjadikan Isa di dalam rahim Maryam "...dengan tiupan roh dari-Nya...” perhatikan juga Qs. $21 \mathrm{Al}$ Anbiyaa 91 "dan (ingatlah kisah) Maryam yang telah memelihara kehormatannya, lalu Kami tiupkan ke dalam (tubuh)nya roh dari Kami." Sesungguhnya, Allah yang telah memberikan kepada Adam, tanpa melalui ayah dan ibu, suatu kehidupan yang berbeda dari kehidupan semua manusia dengan meniupkan roh ciptaan-Nya kepadanya, maka Dia pulalah yang memberi kehidupan kepada Isa tanpa melalui ayah,

\footnotetext{
${ }^{95}$ Lihat Lampiran B-9.

${ }^{96}$ Lihat Lampiran B-1.

${ }^{97}$ Lihat Lampiran B-2.

${ }^{98}$ Lihat Lampiran B-3.
} 
dengan kehidupan seperti manusia lain. ${ }^{99}$ Kedua, kalimat-Nya berarti keberadaannya sebagai ciptaan yang hanya terlaksana dengan kalimatNya. Kalimat bisa berarti perkataan kun, Adam bisa disebut kalimatullah tapi umumnya hanya Isa yang disebut kalimatullah. Isa disebut kalimat Allah dalam arti Isa diciptakan dengan perkataan kun. Mengapa dikatakan rasulullah wa kalimatuhu karena Isa diragukan kerasulannya oleh orangorang Yahudi dan inilah jawaban Allah kepada mereka. ${ }^{100}$ Ketiga, seorang Informan merunjuk Qs. 3 Ali Imran 45 dan menjelaskan bahwa dalam konteks ini, kata kalimat bukanlah gelar tetapi pernyataan Allah tentang penciptaan Isa. (lihat catatan kaki dalam Al Quran 193.) ${ }^{101}$ Keempat, seorang Informan menjawab bahwa ayat ini berhubungan dengan Qs. 3 Ali Imran 45, Isa disebut ciptaan-Nya sama seperti ciptaan lainnya. ${ }^{102}$

Seorang Informan menjelaskan bahwa kata kalimat-Nya berhubungan dengan Isa sebagai utusan Allah, kata kalimah dalam ayat ini hanya menegaskan bahwa Isa Almasih hanya seorang utusan Allah. Sama dengan nabi-nabi/utusanutusan yang lain yang oleh orang Islam wajib diyakini adanya, demikian pula penghormatannya. ${ }^{103}$

\section{Shahih Bukhary No. 1496}

Semua Informan sependapat bahwa kata "dan kalimah-Nya" dalam pertanyaan "Apakah pemahaman Anda tentang "dan kalimah-Nya" (wakalimatuhu) dalam Hadits Shahih Bukhari no. $1496^{104}$ berarti ciptaan atau makhluk ciptaan-

\footnotetext{
${ }^{99}$ Lihat Lampiran B-5.

${ }^{100}$ Lihat Lampiran B-7.

${ }^{101}$ Lihat Lampiran B-6.

${ }^{102}$ Lihat Lampiran B-8.

${ }^{103}$ Lihat Lampiran B-4.

${ }^{104}$ Dari Ubadah r.a., dari nabi s.a.w., beliau bersabda: "Siapa yang mengaku bahwa tiada Tuhan melainkan Allah, Esa, dan tiada bersekutu, muhamad hamba-Nya dan rasul-Nya, 'Isa hamba Allah, Rasul-Nya dan kalimah-Nya (makhluk-Nya) yang disampai-kan-Nya kapada Maryam dan ruh daripada-Nya dan bahwa surga dan neraka itu sebenarnya, maka orang-orang itu akan dimasukkan Tuhan ke dalam surga menurut amalnya." Shahih Bukhari, Jilid I. pen. H. Zainuddin Hamady, dkk.,
} (Jakarta: Widjaya, 1992), 208
Nya. Kata Kalimah-Nya berarti tanda/bukti kekuasaan-Nya dan sama dengan ciptaan. Berikut pendapat para Informan, pertama, kalimat-Nya berarti tanda/bukti kekuasaan-Nya, atau ciptaan-Nya, ini berarti matahari, bulan, bintang dan lain-lain dapat disebut kalimat. ${ }^{105}$ Kedua, kata kalimah berarti Isa adalah makhluk ciptaan Allah. Kata kalimah, sama dengan makhluk, sama dengan fisik. ${ }^{106}$ Ketiga, kalimahNya berarti makhluk ciptaan-Nya. ${ }^{107}$ Keempat, sama dengan penjelasan terhadap pertanyaan yang sama terhadap Al Quran. Kata kalimah-Nya berarti ciptaan yang diciptakan dengan kun. ${ }^{108}$ Kelima, Hadits ini menjelaskan bahwa Isa adalah ciptaan-Nya. ${ }^{109}$ Keenam, kata dan kalimah-Nya berarti ciptaan-Nya. Ini mendukung ayat-ayat Al Quran. ${ }^{110}$ Ketujuh, sebagai penegasan bahwa Isa Almasih, sama seperti Nabi Muhammad adalah utusan Allah. ${ }^{111}$

\section{Shahih Muslim 46}

Pertanyaan keempat mendapat delapan jawaban bahwa ungkapan "dan kalimat-Nya" berhubungan dengan penciptaan, mengulangi jawaban atas tiga pertanyaan sebelumnya. ${ }^{112}$ Satu jawaban menjelaskan bahwa kalimah berarti ketetapan (kekuasaan Allah). ${ }^{113}$

Jawaban terhadap pemahaman tentang kata kalimah dalam hubungan dengan Isa Almasih adalah sebagai berikut, Pertama, kata kalimah berhubungan dengan tanda/bukti kekuasaan. (sembilan dari tigapuluh enam jawaban), Kedua, kata kalimah berati dan berhubungan dengan ciptaan, atau makhluk ciptaan atau proses penciptaan. (duapuluh lima dari tigapuluh enam jawaban), ketiga kata kalimah berarti pemberitahuan (bisikan) kepada

\footnotetext{
${ }^{105}$ Lihat Lampiran B-3.

${ }^{106}$ lihat Lampiran B-1.

${ }^{107}$ Lihat Lampiran B-2.

${ }^{108}$ Lihat Lampiran B-7.

${ }^{109}$ Lihat Qs. 4 An Nisa 171 yang disampaikan kepada Maryam. Lihat Lampiran B-6.

${ }^{110}$ Lihat Lampiran B-8.

${ }^{111}$ Lihat Lampiran B-9.

${ }^{112}$ Lihat Lampiran-lampiran B-1, B-2, B-3, B-5, B-7,

B-6, B-8, B-9.
}

${ }^{113}$ Lihat Lampiran B-4. 
Maryam. ${ }^{114}$ (satu dari tigapuluh enam jawaban), keempat, Kata kalimah berarti utusan Tuhan. ${ }^{115}$ (satu dari tigapuluh enam jawaban)

\section{Pemeriksaan Kredibilitas Data}

\section{Triangulasi Data}

Satu jawaban yang mengatakan bahwa kalimah berarti atau berhubungan dengan pemberitahuan atau bisikan dan demikian juga kalimah berarti atau berhubungan dengan utusan Allah, tidak cukup kredibel sehingga jawaban ini diabaikan.

\section{Interpretasi Data}

Secara umum, ada tiga jawaban mengenai makna kata kalimah dalam hubungan dengan Isa Almasih. Pertama, kata kalimah berarti tandatanda atau bukti kekuasaan Allah; kedua, kata kalimah berarti ciptaan atau berhubungan penciptaan, dan ketiga kata kalimah berarti Allah memberikan kehidupan kepada Isa seperti Allah memberi kehidupan kepada Adam.

Pandangan pertama, tanda-tanda atau bukti kekuasaan Allah. Kata kalimat-Nya berhubungan dengan kuasa Allah dan tandatanda atau bukti kekuasaan-Nya. Tanda kekuasaan itu adalah Maryam menjadi hamil tanpa sentuhan seorang laki-laki. Isa lahir juga karena kekuasaan Allah. Bukan hanya kehamilan Maryam yang menjadi tanda kekuasaan-Nya tetapi kelahiran Isapun menjadi tanda atau bukti kekuasaan Allah.

Dengan kekuasaan-Nya, Allah dapat menciptakan segala sesuatu. Isa dikatakan sebagai sebuah kekhususan, karena penciptaannya berbeda dan tidak seperti manusia lain pada umumnya. Kata kalimah yang dipandang sebagai Kekuasaan Tuhan juga mempunyai arti bahwa kehamilan dan kelahiran Isa terjadi hanya atas izin, kehendak dan kemauan-Nya. Tidak ada hal lain yang dapat membuat Allah menciptakan Isa seperti itu.

\footnotetext{
${ }^{114}$ Qs. 3 Ali Imran 45, lihat Lampiran B-2.

${ }^{115}$ Qs. 4 An Nisa 171, lihat Lampiran B-4.
}

Semuanya adalah dari kehendak-Nya sendiri dari ketetapan Allah.

Tanda atau bukti kekuasaan-Nya juga menunjukkan bahwa Isa adalah sama dengan ciptaan Allah yang lain, matahari, bulan, bintang, hewan, tanaman, dan manusia lainnya dan lain-lain, semua dapat disebut kalimat Allah. Isa sebagai ciptaan sama dengan ciptaan Allah yang lain.

Pandangan kedua berarti ciptaan atau berhubungan dengan penciptaan. Semua informan sepakat mengangkat ungkapan kun fa yakun untuk menunjukkan bahwa Isa adalah ciptaan yang gaib, sesuatu yang di luar jangkauan akal sehat manusia, seorang gadis perawan dapat hamil tanpa sentuhan seorang laki-laki, dan kalimat kun fa yakun itulah penyebabnya.

Penciptaan Isa yang gaib dan unik inipun dalam arti kalam hawadits. Isa adalah ciptaan yang sifatnya baru bukan kekal. Isa tidak sudah ada sejak kekal, tetapi baru ada saat Allah mengucapkan kata kun, dan kata kun menunjukkan suatu perintah yang mengakibatkan sebuah proses fa yakun, Jadi Isa adalah ciptaan dan sesuatu yang "baru" Isa diciptakan dengan kalimat dari-Nya (a word from Allah) dan bukan kalimat Allah (word of Allah). Kata kalimah menunjukkan bahwa sebagai ciptaan, Isa adalah makhluk (istilah yang digunakan untuk membedakan ciptaan dari Pencipta) dan bagi umat Islam makhluk selalu berarti ciptaan. Kata kalimah berarti Allah memberikan kehidupan kepada Isa seperti Allah memberi kehidupan kepada Adam. Kata kalimah juga berarti seperti Allah telah memberikan kepada Adam suatu kehidupan yang berbeda dari kehidupan semua manusia dengan meniupkan roh ciptaan-Nya kepadanya, maka Dia pulalah yang memberi kehidupan kepada Isa. Isa tercipta dengan tiupan roh dariNya (spirit from God)

\section{Penutup}

Masalah atau fokus penelitian "pemahaman umat Islam tentang kata kalimah dalam hubungan dengan Isa Almasih didasarkan pada Al Qur'an dan Hadits tidak dimaksudkan untuk 
menentukan mana yang benar dan yang salah (verifikasi) tetapi untuk mencari penjelasan dari versi Islam tentang Isa Almasih dan untuk memperoleh pandangan yang obyektif terhadap ajaran Islam yang diharapkan dapat menambah pengertian baru tentang pemahaman umat Islam terhadap tema Isa Almasih.

Sebagai hasil diperoleh tiga pandangan mengenai makna kata kalimah dalam hubungan dengan Isa Almasih. Pertama, kata kalimah berarti tanda-tanda atau bukti kekuasaan Allah. Bukan hanya kehamilan Maryam yang menjadi tanda kekuasaan-Nya tetapi kelahiran Isapun menjadi tanda atau bukti kekuasaan Allah. Allah, dengan kekuasaan-Nya, menciptakan segala sesuatu termasuk Isa. Kelahiran Isa terjadi hanya atas izin, kehendak dan kemauan-Nya. Isa adalah sama dengan ciptaan Allah yang lain, semua dapat disebut kalimat Allah.

Kedua, kata kalimah berarti ciptaan atau berhubungan penciptaan. Semua informan sepakat mengangkat ungkapan kun fa yakun untuk menunjuk kepada Isa adalah ciptaan. Penciptaan Isa yang gaib dan unik ini bersifat baru. Isa tidak sudah ada sebelum diciptakan, tetapi baru ada saat Allah mengucapkan kun fa yakun. Isa diciptakan oleh word from Allah, bukan a Word of Allah.

Ketiga kata kalimah berarti Allah memberikan kehidupan kepada Isa seperti Allah memberi kehidupan kepada Adam. Allah memberikan kepada Adam kehidupan dengan cara yang berbeda dari semua manusia yaitu dengan meniupkan roh kepadanya, demikian pula dengan Isa yang tercipta dengan tiupan roh dari-Nya (spirit from God).

\section{Kepustakaan}

Alkitab, Lembaga Alkitab Indonesia. Jakarta: LAI. 1974

Al Quran dan Terjemahnya, diterbitkan untuk Departemen Agama Republik Indonesia. Semarang: CV Toha Putra. 1989

Shahih Bukhari. Jilid I. pen H. Zainuddin Hamady, dkk. Jakarta: Widjaya. 1992
Alkaf, Idrus H., pen. Ikhtisar Hadits Shahih Bukhary. Surabaya: C. V. Karya Utama. t.th.

Bahreisj, Hussein. Al Jami'ush Shahih, (Hadits Shahih): Bukhary Muslim. Surabaya: CV Karya Utama. t.th.

Bakker, J. Piagam Konsili Vatikan II. Yogyakarta: Kanisius. 1972

Ben Abraham, Suradi. Rahasia Jalan ke Surga. Jakarta: Dakwah Ukhuwah. traktat. t. th

bin Katsier, Ismail. Terjemah Singkat Tafsir Ibnu Katsier. Jilid II. Pen. Salim Bahreisy dan Said Bahreisy. Surabaya: Bina Ilmu. t.th.

Burhanuddin, Riva'i. Sejarah Alkitab dan Al Qur'an. Jakarta: C.V. Baru. 1981

Ellis, D. W., Metode Penginjilan. Jakarta: Yayasan Komunikasi Bina Kasih/OMF. 1989

Gani, Bustami A. dkk. Al Qur'an dan Tafsirnya. 10 jilid. Jakarta: Departemen Agama RI. 1993

Hasan, A. Qadir. Ilmu Mushthalah Hadits. Bandung: C.V. Diponegoro. 1994

Irianto, Heru dan Burhan Bungin. Pokok-pokok Penting tentang Wawancara dalam Burhan Bungin, Peny., Metode Penelitian Kualitatif. Jakarta: PT RajaGrafindo Persada. 2001.

Lubis, H. M. Arsyad Thallib. Imam Mahdi. Medan: Firma Islamiyah. 1967

Mahalaliy, Jalaluddin Al dan Jalaluddin As Suyuthi, Tafsir Jalalain berikut Asbaabun Nuzul, 4 jilid. Pen. Mahyudin Syaf dan Bahrun Abubakar. Bandung: Sinar Baru, 1990

Moleong, Lexy. Metodelogi Penelitian Kualitatif. Bandung: PT Remaja Rosdakarya. 2002

Mulyana, Deddy Metodologi Penelitian Kualitatif: Paradigma Baru Ilmu Komunikasi dan Ilmu Sosial Lainnya. Bandung: PT Remaja RosdaKarya. 2001.

Munawwir, Achmad W. Kamus Al Munawwir: Arab Indonesia Terlengkap. Surabaya: Pustaka Progresif. 1997

Nasr, S. H., Islam dalam Cita dan Fakta, pen. Abdurrahman Wahid dan Hashim 
Wahid. Jakarta: Lembaga Penunjang Pembangunan Nasional. 1983

Nasution, Harun. Islam Ditinjau dari Berbagai Aspeknya. Vol. I, II. Jakarta: UI Press. 1974

Rathomy, Mohammad Abdai. Inilah Hari Pembalasan. Bandung: PT Al Maiarif. t.th.

Sairin, Wienata. Tempat dan Peran Yesus di Hari Kiamat: Menurut Ajaran Islam. Jakarta: Pustaka Sinar Harapan. 1997

Saudah, Ali. Konkordansi Qur'an: Panduan Kata dalam Mencari Ayat Qur'an. Bogor: Pustaka Litera AntarNusa. 1996

Sevilla, Consuelo G. dkk. Pengantar Metode Penelitian. pen. Alimuddun Tuwu. Jakarta: Penerbit Universitas Indonesia (UI-Press). 1993

Suprayogo, Imam dan Tobroni, Metodologi Penelitian Sosial-Agama. Bandung: Remaja Rosdakarya, 2001

Syarqawy, Muhammad Abdullah, Yesus dalam Pandangan Al-Ghazali: Analisa Pemikir Besar Islam tentang Dogma Trinitas. Pen. Hasan Abrori. Peny. Masyhud SM dan Ibnu Hasan, t. tp.: Pustaka Da'i. 1994

Turabian, Kate L. A Manual for Writers of Term Papers, Theses and Disertations, Sixth Edition. Chicago and London: The University of Chicago Press. 2001.

Yunus, H. Mahmud, Kamus Arab-Indonesia. Jakarta: PT Hidakarya Agung. 1972

Buku yang Tidak Diterbitkan

Agusman. P. Sedapat Mungkin: Aspek-aspek Komunikasi Lintas Budaya. t. tp.: oleh penulis. 1996

Amos, H. Upacara Ibadah Haji. Jakarta: oleh penulis. 1997.
Ben Abraham, Suradi, Penginjilan Pribadi. t. tp.: oleh Penulis, t.th

Soedarso, Yoseph. Riwayat Hidup Muhammad dan Pokok-pokok Ajaran Islam. Diktat Kuliah Islamologi. Semarang: STBI. t. th.

Wedha, Edhi Sapto. Islamologi. t. tp: oleh Penulis. fotokopi. t. th.

\section{Program Komputer}

The World of Islam: Resources for Understanding. [CD-ROM]. Pasadena, California: Global Mapping International. 2000.

Yayasan Lembaga Sabda (YLSA)/Online Bible Versi Indonesia. Sofware Alkitab Biblika dan Alat-alat (SABDA). [CD-ROM]. Surakarta: OLB/YLSA. 1997-99.

\section{Wawancara}

Kinontoa, Mazhar. Wawancara dengan Peneliti, Pedoman Wawancara. Manado.

Hamang, M. Nasri. Wawancara dengan Peneliti. Pedoman Wawancara. Manado.

Maidin. Muhamammad Sabir. Wawancara dengan Peneliti. Pedoman Wawancara. Manado.

Mastur. Wawancara dengan Peneliti, Pedoman Wawancara. Manado.

Mursyid. Salma. Wawancara dengan Peneliti, Pedoman Wawancara. Manado.

Sofyan Lahilote. Wawancara dengan Peneliti, Pedoman Wawancara. Manado. 


\section{Lampiran A}

PEDOMAN WAWANCARA

PEMAHAMAN UMAT ISLAM TENTANG KATA KALIMAH DALAM HUBUNGAN DENGAN ISA ALMASIH

\section{PERTANYAAN-PERTANYAAN PENUNTUN}

1. Apakah Makna kata kalimah(كَلَِ) dalam ajaran Islam?

2. Apakah pemahaman Anda tentang "dengan kalimat daripada-Nya" (bikalimatin minhu) dalam Qs 3 Ali Imran 45?

3. Apakah pemahaman Anda tentang "dan kalimat-Nya" (wakalimatuhu) dalam Qs 4 An Nisa 171 ?

4. Apakah pemahaman Anda tentang "dan kalimah-Nya" (wakalimatuhu) dalam Hadits Shahih Bukhari no. 1496

5. Apakah pemahaman Anda tentang "serta kalimat-Nya" (wakalimatuhu) Hadits Sahih Muslim 46 


\section{Lampiran B-1}

PEDOMAN WAWANCARA

PEMAHAMAN UMAT ISLAM TENTANG KATA KALIMAH DALAM HUBUNGAN DENGAN

ISA ALMASIH

\section{N A M A $\quad:$ MNH}

\section{PERTANYAAN-PERTANYAAN PENUNTUN}

1. Apakah Makna kata kalimah(كَلََِ) dalam ajaran Islam?

Secara etimologi, kata kalimah bisa berarti Mujizat, keterangan, ilham, tanda-tanda, hukum-hukum, aturan-aturan, dan lain-lain. Seperti "Kalimatut Tauhid" artinya "kalimat mengesakan Tuhan”.

2. Apakah pemahaman Anda tentang "dengan kalimat daripada-Nya" (bikalimatin minhu) dalam Qs 3 Ali Imran 45?

Kata kalimah bisa berarti tanda-tanda, bisa berarti ilham. Dalam ayat ini kata kalimah berarti tanda-tanda akan kelahiran seorang anak (kehamilan) dari Tuhan. Isa adalah pembuktian kemahakuasaan Tuhan. Kelahiran Isa adalah seperti kelahiran tiga orang lainnya dalam Al Qur'an yaitu Ishak yang lahir waktu Ibrahim sudah sangat tua, istrinya mandul dan tidak mungkin lagi punya anak. Kemudian nabi Yahya di mana nabi Zakharia juga sudah tua dan istrinya mandul. Yang ketiga...[informan lupa]. Dan yang terakhir adalah Isa. Semuanya lahir sebagai bukti kemahakuasaan Allah.

3. Apakah pemahaman Anda tentang "dan kalimat-Nya" (wakalimatuhu) dalam Qs 4 An Nisa 171 ?

Arti kalimah dalam ayat ini adalah kekuasaan-Nya

Maksudnya Isa lahir atas kekuasaan Allah.

4. Apakah pemahaman Anda tentang "dan kalimah-Nya" (wakalimatuhu) dalam Hadits Shahih Bukhari no. 1496

Kata kalimah dalam ayat ini berarti ciptaan maksudnya Isa adalah makhluk cipaan Allah. Kalimat sama dengan makhluk, sama dengan fisik.

5. Apakah pemahaman Anda tentang "serta kalimat-Nya" (wakalimatuhu) Hadits Sahih Muslim 46

Sama maknanya dengan Bukhary 1496: Isa tercipta karena kekuasaan dan kehendak Tuhan. Bahwa Allah dapat berbuat apa yang dikehendaki-Nya. 


\section{Lampiran B-2}

PEDOMAN WAWANCARA

PEMAHAMAN UMAT ISLAM TENTANG KATA KALIMAH DALAM HUBUNGAN DENGAN

ISA ALMASIH

N A M A

: MSM

\section{PERTANYAAN-PERTANYAAN PENUNTUN}

1. Apakah Makna kata kalimah (كَلََ) dalam ajaran Islam?

Secara terminologi, dari kata kalam. Kalam Allah berarti Ucapan Allah.

2. Apakah pemahaman Anda tentang "dengan kalimat daripada-Nya" (bikalimatin minhu) dalam Qs 3 Ali Imran 45?

Kata kalimah berasal dari kata kalam yang berarti ucapan. Kalamullah berarti ucapan Allah. Kata kalimat daripadanya berarti pemberitahuan (bisikan) kepada Maryam bahwa Maryam akan mempunyai putera yang kejadiannya seperti nabi Adam yang tidak punya bapak.

3. Apakah pemahaman Anda tentang "dan kalimat-Nya" (wakalimatuhu) dalam Qs 4 An Nisa 171 ?

"Dan kalimat" berarti kekuasaan Tuhan yang atas izin, kehendak dan kemauannya untuk menjadikan Isa tanpa seorang bapak. Hubungannya dengan Isa Almasih, ayat ini menjelaskan kepada kaum ahlul kitab bahwa jangan terlalu mengada-ada (membuat keputusan yang berlebihan), tentang Allah karena Isa hanyalah utusan Allah.

4. Apakah pemahaman Anda tentang "dan kalimah-Nya" (wakalimatuhu) dalam Hadits Shahih Bukhari no. 1496

Semua nabi/Rasul (Muhammad, Isa dan lain-lain) menyatakan bahwa tidak ada Tuhan selain daripada Allah. Dan dilarang mempersekutukan, dilarang menyembah selain daripada Allah.

kalimah-Nya berarti "makhluk ciptaannya".

5. Apakah pemahaman Anda tentang "serta kalimat-Nya" (wakalimatuhu) Hadits Sahih Muslim 46

Ditekankan bahwa Isa adalah hamba Allah serta makhluk ciptaan-Nya.

Kata kalimat-Nya berarti "Kekuasaan-Nya" 


\section{Lampiran B-3}

PEDOMAN WAWANCARA

PEMAHAMAN UMAT ISLAM TENTANG KATA KALIMAH DALAM HUBUNGAN DENGAN

ISA ALMASIH

N A M A $\quad$ : SM

PERTANYAAN-PERTANYAAN PENUNTUN

1. Apakah Makna kata kalimah (كَ) dalam ajaran Islam?

Kata kalimah berarti kata-kata.

2. Apakah pemahaman Anda tentang "dengan kalimat daripada-Nya" (bikalimatin minhu) dalam Qs 3 Ali Imran 45?

Kata kalimah dalam ayat ini berarti tanda-tanda kekuasaan-Nya.

3. Apakah pemahaman Anda tentang "dan kalimat-Nya" (wakalimatuhu) dalam Qs 4 An Nisa 171 ?

Kalimat-Nya berarti tanda/bukti kekuasaan-Nya, atau ciptaan-Nya Dalam arti ciptaan; matahari, bulan bintang dan lain-lain. Semuanya dapat disebut kalimat.

4. Apakah pemahaman Anda tentang "dan kalimah-Nya" (wakalimatuhu) dalam Hadits Shahih Bukhari no. 1496

Sama saja dengan kedua ayat Al Qur'an di atas bahwa kata wakalimatuhu berarti tanda atau bukti kekuasaan Allah, Isa adalah makhluk-Nya.

5. Apakah pemahaman Anda tentang "serta kalimat-Nya" (wakalimatuhu) Hadits Sahih Muslim 46

Sebenarnya Hadits ini mengulangi apa yang dikatakan Bukhary. Hadits ini adalah hadits yang sama. Jadi jawabnya sama, bahwa wakaliamtuhu berarti tanda kekuasaan Allah. 


\section{Lampiran B-4}

PEDOMAN WAWANCARA

PEMAHAMAN UMAT ISLAM TENTANG KATA KALIMAH DALAM HUBUNGAN DENGAN

ISA ALMASIH

N A M A

: MST

PERTANYAAN-PERTANYAAN PENUNTUN

1. Apakah Makna kata kalimah (كَلََمَ) dalam ajaran Islam?

a. Kata kalimah berarti Firman Allah/Ucapan Allah. Tetapo kata kalimah tidak selalu diartikan firman.

b. Kata kalimah bisa berarti "Ujian"

c. Kata kaliamh juga bisa berarti "ketetapan"

Kata kalimah sebagai Firman/ucapan/omongan memiliki dua pengertian

a. kalimat berarti firman Allah yang disebut "Kalam Qodim" sifatnya kekal.

b. Kalimat berarti omongan/ucapan sesama makhluk termasuk omongan para nabi/Rasul yang disebut "Kalam Hawadits" sifatnya "baru".

2. Apakah pemahaman Anda tentang "dengan kalimat daripada-Nya" (bikalimatin minhu) dalam Qs 3 Ali Imran 45?

Kata bikalimatin minhu berarti membenarkan kedatangan seorang nabi (bukan Tuhan) yang diciptakan dengan kalimat "kun" (jadilah) tanpa seorang Bapak yaitu nabi Isa As. Dalam hal ini hubungannya dengan Isa Almasih (Yesus) bahwa Maryam mengandung dan melahirkan nabi Isa tanpa Suami. Ketika Maryam pulang membawa bayinya; orang yahudi menuduh bahwa Maryam berbuat zina. Untuk membersihkan tuduhan itu maka Allah berfirman (sebagai penyangkal) bahwa Roh yang ada dalam rahim Maryam adalah Roh (milik) Allah, dalam arti kalam hawadits, sifatnya "baru" bukan kekal. Isu waktu itu Isa lahir dari seorang perempuan tanpa suami sehingga menjadi perhatian umat. Kalimat alah artinya tanda kekuasaan Allah. Semua ciptaan Allah dapat disebut kalimat Allah. (sunnatullah)

3. Apakah pemahaman Anda tentang "dan kalimat-Nya" (wakalimatuhu) dalam Qs 4 An Nisa 171 ?

Kata kalimat dalam ayat ini hanya menegaskan bahwa Isa Almasih hanya seorang utusan Allah. Sama dengan nabi-nabi/utusan-utusan yang lain yang oleh orang Islam wajib diyakini adanya demikian pula penghormatannya.

4. Apakah pemahaman Anda tentang "dan kalimah-Nya" (wakalimatuhu) dalam Hadits Shahih Bukhari no. 1496

Ayat ini mempertegas bahwa nabi Isa hanyalah Hamba Allah dan Rasul Allah (utusan Allah) kepada orang-orang yahudi yang akan mengembalikan kekuasaan bani Israil yang telah hilang.

5. Apakah pemahaman Anda tentang "serta kalimat-Nya" (wakalimatuhu) Hadits Sahih Muslim 46

Menafsirkan dan mempertegas bahwa nabi Isa adalah Hamba Allah. Kalimat berarti ketetapan (kekuasaan Allah). 


\section{Lampiran B-5}

PEDOMAN WAWANCARA

PEMAHAMAN UMAT ISLAM TENTANG KATA KALIMAH DALAM HUBUNGAN DENGAN

ISA ALMASIH

N A M A : SL

PERTANYAAN-PERTANYAAN PENUNTUN

1. Apakah pemahaman Anda tentang "dengan kalimat daripada-Nya" (bikalimatin minhu) dalam Qs 3 Ali Imran 45?

Yang dimaksud dengan kata kalimat adalah kalimat (Firman) dari Allah yaitu "kun" (jadilah). Lihat juga penjelasan dari Ali Imran 59 yang masih dalam konteks yang sama, "Sesungguhnya misal (penciptaan) Isa disisi Allah adalah seperti (Penciptaan) Adam. Allah menciptakan Adam dari tanah, kemudian Allah berfirman kepadanya, jadilah (seorang manusia) maka jadilah dia.”

2. Apakah pemahaman Anda tentang "dan kalimat-Nya" (wakalimatuhu) dalam Qs 4 An Nisa 171 ?

Penafsiran yang paling dekat terhadap ungkapan ini adalah bahwa Allah menciptakan Isa Almasih dengan perintah "kun” 'jadilah' secara langsung, sebagaimana yang disebut dalam beberap ayat Al Quran yaitu "kun fa yakun”, 'jadilah maka jadilah'. Kalimat inilah yang disampaikan kepada Maryam. Maka terciptalah Isa di dalam rahimnya tanpa sperma seorang ayah, sebagaimana biasanya dalam kehidupan manusia selain Adam. Kalimat yang dapat menjadikan segala sesuatu ini ("kun") dari tidak ada menjadi ada tidak mengherankan kalau ia menjadikan Isa a.s. di dalam rahim Maryam dari tiupan ygdiungkapkan dengan firman-Nya "...dan dengan tiupan roh dari-Nya..." perhatikan juga Qs. $21 \mathrm{Al}$ Anbiyaa 91 "dan (ingatlah kisah) Maryam yang telah memelihara kehormatannya, lalu Kami tiupkan ke dalam (tubuh)nya roh dari Kami."

Sesungguhnya, Allah yang telah memberikan kepada Adam tanpa melalui ayah dan ibu suatu kehidupan yang berbeda dari kehidupan semua manusia dengan meniupkan roh ciptaan-Nya kepadanya, maka Dia pulalah yang memberi kehidupan kepada Isa tanpa melalui ayah, dengan kehidupan seperti manusia lain.

3. Apakah pemahaman Anda tentang "dan kalimah-Nya" (wakalimatuhu) dalam Hadits Shahih Bukhari no. 1496

"Telah jelas"

4. Apakah pemahaman Anda tentang "serta kalimat-Nya" (wakalimatuhu) Hadits Sahih Muslim 46

"Telah jelas" 


\section{Lampiran B-6}

PEDOMAN WAWANCARA

PEMAHAMAN UMAT ISLAM TENTANG KATA KALIMAH DALAM HUBUNGAN DENGAN

ISA ALMASIH

N A M A $\quad:$ MK

PERTANYAAN-PERTANYAAN PENUNTUN

1. Apakah Makna kata kalimah (كَلََمَ) dalam ajaran Islam?

Dari kata "Kalam" yang artinya "perkataan".

2. Apakah pemahaman Anda tentang "dengan kalimat daripada-Nya" (bikalimatin minhu) dalam Qs 3 Ali Imran 45?

Kata kalimat berasal dari kata "kalam" artinya perkataan. Kata bikalimatin minhu maksudnya adalah dengan kata kun = jadilah bandingkan dengan 3:59 tentang penciptaan Adam. Allah berfirman kun fayakun maka jadilah Isa. Bedanya Isa dikandung oleh Maryam, Adam tidak karena manusia pertama. Lihat juga catatan kaki Al Quran nomor 193.

kun adalah perintah - fayakun adalah proses lihat konteks ceritanya (3:46-47) dengan kalimat-Nya maka Isa tercipta.

3. Apakah pemahaman Anda tentang "dan kalimat-Nya" (wakalimatuhu) dalam Qs 4 An Nisa 171 ?

Lihat juga Qs. 3 Ali Imran 45. dalam konteks ini kata "kalimat" bukanlah gelar Isa tetapi pernyataan Allah tentang penciptaan "kun" Isa. (lihat catatan kaki dalam Al Quran nomor 193.)

4. Apakah pemahaman Anda tentang "dan kalimah-Nya" (wakalimatuhu) dalam Hadits Shahih Bukhari no. 1496

Hadits ini menjelaskan bahwa Isa adalah ciptaan-Nya. Lihat penjelasan Qs. 4:171 tentang "yang disampaikan kepada Maryam."

5. Apakah pemahaman Anda tentang "serta kalimat-Nya" (wakalimatuhu) Hadits Sahih Muslim 46

Hadits ini mirip dengan Hadits Shahih Bukhary di atas. Penejelasannya sama. 


\section{Lampiran B-7}

PEDOMAN WAWANCARA

PEMAHAMAN UMAT ISLAM TENTANG KATA KALIMAH DALAM HUBUNGAN DENGAN

ISA ALMASIH

\section{N A M A $\quad$ : AA}

\section{PERTANYAAN-PERTANYAAN PENUNTUN}

1. Apakah pemahaman Anda tentang "dengan kalimat daripada-Nya" (bikalimatin minhu) dalam Qs 3 Ali Imran 45?

Ketika malaikat berkata kepada Maryam, malaikat Jibril membeawa kabar gembira dari Allah bahwa Maryam akan mendapat seorang putera yang terkemuka di dinua dan akhirat, tapi Maryam bingung karena belum pernah disentuh laki-laki. Malakat Jibril berkata bahwa tidak ada yang mustahil bai Allah. Allah cukup mengatakan saja "kun fa yakun" kata "dengan kalimat dari padanya" berarti pencptaan Isa Almasih dengan hanya mengatakan "kun fa yakun"

2. Apakah pemahaman Anda tentang "dan kalimat-Nya" (wakalimatuhu) dalam Qs 4 An Nisa 171 ?

Kalimatnya berarti keberadaannya sebagai ciptaan yang hanya terlaksana dengan kalimatNya. Kalimat bisa erarti perkataan (kun) Adam bisa disebut kalimatullah tapi umumnya hanya Isa yang disebut kalimatullah. Isa disebut kalimat Allah dalam arti Isa diciptakan dengan perkataan "kun" mengapa dikatakan rasulullah wa kaliamtuhu karena Isa diragukan kerasulannya oleh orang-orang yahudi dan ini adalah jawaban Allah terhadap mereka.

3. Apakah pemahaman Anda tentang "dan kalimah-Nya" (wakalimatuhu) dalam Hadits Shahih Bukhari no. 1496

Penjelasan tentang pertanyaan dalam hadits sebenarnya sama saja dengan penjelasan terhadap pertanyaan yang sama dlama Al Quran. Kata kalimatnya berarti ciptaan-Nya yang diciptakan dengan "kun"

4. Apakah pemahaman Anda tentang "serta kalimat-Nya" (wakalimatuhu) Hadits Sahih Muslim 46

Sama dengan pejelasan untuk ayat-ayat Al Quran yaitu kalimatnya berarti ciptaannya 


\section{Lampiran B-8}

PEDOMAN WAWANCARA

PEMAHAMAN UMAT ISLAM TENTANG KATA KALIMAH DALAM HUBUNGAN DENGAN

ISA ALMASIH

\section{N A M A $\quad$ : AL}

\section{PERTANYAAN-PERTANYAAN PENUNTUN}

1. Apakah pemahaman Anda tentang "dengan kalimat daripada-Nya" (bikalimatin minhu) dalam Qs 3 Ali Imran 45?

Kata kalimah berarti ciptaan Tuhan. Ada penegasan yang lebih meyakinkan bahwa Isa adalah nabi yang diciptakan.

2. Apakah pemahaman Anda tentang "dan kalimat-Nya" (wakalimatuhu) dalam Qs 4 An Nisa 171 ?

Semua nabi termasuk Isa adalah utusan Allah yang menyampaikan wahyu Allah. Isa lamasih sejak lahir sudah jadi nabi. Berbeda dengan Muhammad yang dipanggil menjadi nabi pada usia 40 tahun. Isa adalah kekhususan, tidak seperti manusia biasa. Maryam hamil karena "kuasa Allah". Dapat dikatakan hal ini adalah sesuatu yang gaib karena penciptaannya dengan kalimat kun fa yakun.

3. Apakah pemahaman Anda tentang "dan kalimah-Nya" (wakalimatuhu) dalam Hadits Shahih Bukhari no. 1496

Penegasan bahwa Isa Almasih seperti Nabi Muhammad sebagai utusan Allah. Kata kalimah-Nya berarti ciptaan-Nya.

4. Apakah pemahaman Anda tentang "serta kalimat-Nya" (wakalimatuhu) Hadits Sahih Muslim 46

Konteks hadits ini sama dengan surat Qs. 4 An Nisa di atas. Hadits ini menegaskan keesaan Allah bahwa Isa Almasih dan Muhammad tidak disejajarkan dengan Allah. Kata kalimat-Nya berarti proses penciptaan. 


\section{Lampiran B-9}

PEDOMAN WAWANCARA

PEMAHAMAN UMAT ISLAM TENTANG KATA KALIMAH DALAM HUBUNGAN DENGAN

ISA ALMASIH

\section{N A M A : AKA}

\section{PERTANYAAN-PERTANYAAN PENUNTUN}

1. Apakah pemahaman Anda tentang "dengan kalimat daripada-Nya" (bikalimatin minhu) dalam Qs 3 Ali Imran 45?

Kata dengan kalimat daripadanya berarti Isa diciptakan dengan kaliamt kun fa yakun.

Perhatikan Qs 3 Ali Imran 47. cerita ini dimulai dari ayat 42 sampai 63. kata kalimat (kun) fa yakun) adalah proses. Jadi kelahiran Isa adalah melalui proses yang dimulai dengan kalimat (kun).

2. Apakah pemahaman Anda tentang "dan kalimat-Nya" (wakalimatuhu) dalam Qs 4 An Nisa 171 ?

Ada hubungan dengan Qs 3 Ali Imran 45, Isa disebut "ciptaan-Nya” sama seperti ciptaan lainnya melalui proses.

3. Apakah pemahaman Anda tentang "dan kalimah-Nya" (wakalimatuhu) dalam Hadits Shahih Bukhari no. 1496

Kata dan kalimah berarti ciptaan-Nya. Ini mendukung Ayat-ayat Al Quran.

4. Apakah pemahaman Anda tentang "serta kalimat-Nya" (wakalimatuhu) Hadits Sahih Muslim 46

Hadits ini sama dengan Hadits Shahih Bukhary di atas. Kalimatnya berarti ciptaan-Nya. 